\title{
Effect of Biofertilizer and Integrated Nutrient Management on Growth of Potato and Soil Microbial Activity
}

\author{
R. Chutia ${ }^{1 *}$, P.C. Bhagawati ${ }^{1}$ and D.J. Nath $^{2}$ \\ ${ }^{1}$ Department of Agronomy, ${ }^{2}$ Department of Soil Science, \\ Assam Agricultural University, Jorhat-785013, India \\ *Corresponding author
}

\section{A B S T R A C T}

\section{Keywords \\ Biofertilizer, Soil microbial biomass carbon, \\ Dehydrogenase activity, Phosphomono esterase activity (PMEase activity), Fluorescein di-acetate, Enriched compost, \\ Vermicompost.}

\section{Article Info}

Accepted:

04 October 2017

Available Online:

10 December 2017
Integrated nutrient management through bio-fertilizers, organic fertilizer and chemical fertilizers can sustain soil quality and improve plant growth. A field experiment titled "Effect of Biofertilizer and Integrated Nutrient Management on Growth of Potato and Soil Microbial Activity" was conducted during rabi seasons of 2014-15 and 2015-16 at the instructional cum research farm of Assam agricultural university. The experiment consisting of eight treatments viz., $100 \%$ recommended dose of Nitrogen $\left(\mathrm{T}_{1}\right), 75 \%$ recommended dose of Nitrogen+ 25\% Nitrogen through Enriched Compost $\left(\mathrm{T}_{2}\right), 75 \%$ recommended dose of Nitrogen+ $25 \%$ Nitrogen through Vermicompost $\left(\mathrm{T}_{3}\right), 50 \%$ recommended dose of Nitrogen+ 50\% Nitrogen through Enriched Compost $\left(\mathrm{T}_{4}\right), 50 \%$ recommended of Nitrogen $+50 \%$ Nitrogen through Vermicompost $\left(\mathrm{T}_{5}\right), 50 \%$ recommended dose of Nitrogen $+25 \%$ Nitrogen through Enriched Compost $+25 \%$ Nitrogen through Vermicompost (T6), 50\% recommended dose of Nitrogen $+25 \%$ Nitrogen through Enriched Compost (T7) and 50\% recommended dose of Nitrogen $+25 \%$ Nitrogen through Vermicompost $\left(\mathrm{T}_{\mathbf{8}}\right)$ was laid out in randomized block design with three replications. The soil of the experimental site was sandy loam in texture, acidic (5.66) in reaction, medium in organic carbon $(0.72 \%)$, available $\mathrm{N}(290 \mathrm{~kg} / \mathrm{ha}), \mathrm{P}_{2} \mathrm{O}_{5}(25.78 \mathrm{~kg} / \mathrm{ha})$ and $\mathrm{K}_{2} \mathrm{O}(270.89 \mathrm{~kg} / \mathrm{ha})$.Soil physico-chemical characters at harvest of potato were significantly influenced by INM practices of which $\mathrm{T}_{6}$ (50\% recommended dose of Nitrogen $+25 \%$ Nitrogen through Enriched Compost $+25 \%$ Nitrogen through Vermicompost) recorded the highest values for all the soil parameters viz., soil $\mathrm{pH}(5.58$ and 5.62), soil organic carbon (SOC) (0.96 and 1.08\%), available N (405 and 548.15 $\mathrm{kg} / \mathrm{ha}), \mathrm{P}(23.20$ and $23.96 \mathrm{~kg} / \mathrm{ha})$ and $\mathrm{K}(333.89$ and $336.55 \mathrm{~kg} / \mathrm{ha})$ during both the years of experimentation. Soil biological characters were also found to be statistically superior in respect of microbial biomass carbon (335.55 and $367.41 \mu \mathrm{g} \mathrm{g}^{-1}$ soil), dehydrogenase activity (191.29 and $\left.201.19 \mu \mathrm{g} \mathrm{TPFg}^{-1} 24 \mathrm{hr}^{-1}\right)$, phosphomonoesterase activity (356.44 and $382.46 \mu \mathrm{g} p$-nitrophenol $\left.\mathrm{g}^{-1} \mathrm{hr}^{-1}\right)$, fluorescein di-acetate hydrolysis activity $(9.22$ and 9.26 $\mu \mathrm{g}$ fluorescein $\left.\mathrm{g}^{-1} \mathrm{hr}^{-1}\right)$ at $\mathrm{T}_{6}$ followed by $\mathrm{T}_{4}(50 \%$ recommended dose of Nitrogen $+50 \%$ Nitrogen through Enriched Compost). The Organic carbon showed strong correlation with microbial biomass carbon $\left(\mathrm{r}=0.794^{*}\right)$, Dehydrogenase $\left(\mathrm{r}=0.807^{* *}\right)$ and Available N $(\mathrm{r}=0.700 *)$. Similarly the enzyme phosphomonoesterase established significant correlation with Available $\mathrm{P}_{2} \mathrm{O}_{5}\left(\mathrm{r}=0.668^{*}\right)$ indicating the role of enzyme in releasing the $\mathrm{P}$ from organic sources. 


\section{Introduction}

Potato popularly known as "The king of vegetables" has emerged as fourth most important food crops in India after rice, wheat and maize in terms of dry matter production per unit area per unit time. In world scenario, India became the second largest producer of potato. To meet the food and nutritional demand of the fast growing population of the country like India it is becoming essential to make a futuristic plan. Potato is one of the important crops of the world and is consumed by people across the globe both as food and as vegetable. The post green revolution has witnessed substantial increase in production of food but at the cost of soil health and environmental pollution. Chemical fertilizers are the main source of nutrient to the potato crop. However, continuous cropping and dependence on chemical fertilizers has resulted in nutritional imbalance, depletion of soil organic matter, soil erosion, low availability of water, contamination of food and water, adverse effect on biodiversity as well as on human health. Considering their harmful effects of fertilizers, it is necessary to find out an alternative that besides improving the productivity and quality of potato should also be eco-friendly to the environment. Integrated nutrient management through bio-fertilizers, organic fertilizer and chemical fertilizers can sustain soil quality and improve plant growth. Application of organic manures in conjunction with fertilizers improves physical, chemical and biological properties of the soil besides improving fertilizer use efficiency and crop yield.

\section{Materials and Methods}

A field experiment titled "Effect of biofertilizer and integrated nutrient management on growth of potato and soil microbial activity" was conducted during rabi seasons of 2014-15 and 2015- 16 at the
Instructional-cum-Research farm of Assam Agricultural University. The experiment was laid out in Randomized Block Design with three replications and eight different treatments. Twenty four treatments consisting combination of both organic and inorganic fertilizers were allocated randomly. The experimental farm is located at $26^{\circ} 47^{\prime} \mathrm{N}$ latitude and $94^{\circ} 12^{\prime} \mathrm{E}$ longitude and at the elevation of 86.6 meters above the mean sea level (MSL) and under Upper Brahmaputra Valley Zone of Assam.

A rectangular shaped upland plot $27.5 \mathrm{~m}$ in length and $12 \mathrm{~m}$ in breadth equivalent to 330 $\mathrm{m}^{2}$ was selected prior to the layout of the experiment for the year 2014-15 and 2015-16. The soil of the experimental site was an upland plain belonging to the inceptisol order where different experiments on potato are carried out.

Surface soils up to $0-15 \mathrm{~cm}$ depth were collected from different sites selected at random to determine the physico-chemical properties of the experimental area. The collected composite bulk soil samples were air dried and ground with a wooden roller and finally passed through $0.2 \mathrm{~mm}$ sieve. After thorough mixing, the soil samples were analysed for both physico-chemical properties of the soil. The initial status of the soil has been presented in Table 1 and 2.

\section{Results and Discussion}

Table 3 indicates that applied treatments had significant effect on available $\mathrm{N}$ present in the soil after harvest. The highest available soil nitrogen of $405.00 \mathrm{~kg} / \mathrm{ha}$ and $584.15 \mathrm{~kg} / \mathrm{ha}$ were recorded at $\mathrm{T}_{6}(50 \% \mathrm{RD}$ of $\mathrm{N}+25 \% \mathrm{~N}$ through Enriched compost $+25 \% \mathrm{~N}$ through Vermicompost) during both the years.

This was followed by the values of $384.67 \mathrm{~kg} / \mathrm{ha}$ and $535.06 \mathrm{~kg} / \mathrm{ha}$ at $\mathrm{T}_{4}(50 \% \mathrm{RD}$ 
of $\mathrm{N}+50 \% \mathrm{~N}$ through Enriched compost). The values at $T_{4}$ and $T_{5}$ were statistically at par in 2014-15. While $\mathrm{T}_{4}$ and $\mathrm{T}_{6}$ were found statistically at par in 2015-16.

The lowest value of $301.33 \mathrm{~kg} / \mathrm{ha}$ was recorded at $\mathrm{T}_{\mathbf{8}}$ in 2014-15 and however, $\mathrm{T}_{2}$ $(375.88 \mathrm{~kg} / \mathrm{ha})$ was observed lowest in second year of experimentation.

Different INM practices could not exert significant influence on available phosphorous in soil during both the years. However, highest values of 23.20 and 23.96 $\mathrm{kg} / \mathrm{ha}$ were recorded at $\mathrm{T}_{6}$ in 2014- 15 and 2015-16 respectively (Table 3). 100\% recommended dose of $\mathrm{N}\left(\mathrm{T}_{1}\right)$ recorded the lowest soil available phosphorous of 20.25 and $20.65 \mathrm{~kg} / \mathrm{ha}$ respectively during both the years.

The highest available potassium in soil after harvest of crop was recorded at $\mathrm{T}_{6}(50 \% \mathrm{RD}$ of $\mathrm{N}+25 \% \mathrm{~N}$ through Enriched compost + $25 \% \mathrm{~N}$ through Vermicompost) and the respective values were 333.89 and $336.55 \mathrm{~kg} / \mathrm{ha}$ in 2014-15 and 2015-16 followed by $\mathrm{T}_{4}$ (Table 3). However, the lowest values of 116.00 and $117.53 \mathrm{~kg} / \mathrm{ha}$ respectively were recorded at $T_{1}(100 \%$ recommended dose of $\mathrm{N}$ ) during both the years.

Data recorded on soil $\mathrm{pH}$ at harvest of the crops during 2014-15 and 2015-16 are presented in Table 4.Variation in soil $\mathrm{pH}$ due to effect of INM was not significant during both the years. However, higher values of 5.73 and 5.77 were observed in $\mathrm{T}_{6}$ during both the years. The lowest was recorded in $\mathrm{T}_{1}$ during both the years of experimentation.

Soil organic carbon content was significantly influenced by different treatments (Table 4). The highest per cent organic carbon of 0.92 and 1.08 were recorded at $\mathrm{T}_{6}(50 \% \mathrm{RD}$ of $\mathrm{N}+$
$25 \% \mathrm{~N}$ through Enriched compost $+25 \% \mathrm{~N}$ through Vermicompost) during both the years. The two years data revealed that $T_{1}$ (100\% recommended dose of $\mathrm{N}$ ) recorded the lowest per cent organic carbon of 0.55 and 0.58 . Soil organic carbon values at $\mathrm{T}_{2}, \mathrm{~T}_{\mathbf{4}}, \mathrm{T}_{\mathbf{5}}$, $\mathrm{T}_{7}$ and $\mathrm{T}_{8}$ were at par in 2014-15. However, $\mathrm{T}_{6}$ was highly significant as compared to rest of the treatments during 2015-16.

Data pertaining to soil microbial biomass carbon as affected by different INM practices are presented in Table 5, significant differences in soil biomass carbon were observed with highest values of 335.55 and $367.41 \mu \mathrm{g} \mathrm{g}^{-1}$ soil at $\mathrm{T}_{6}(50 \% \mathrm{RD}$ of $\mathrm{N}+25 \%$ $\mathrm{N}$ through Enriched compost $+25 \% \mathrm{~N}$ through Vermicompost) during 2014-15 and 2015-16, while the lowest soil microbial biomass carbon of $242.35 \mu \mathrm{g} \mathrm{g} \mathrm{g}^{-1}$ soil and $278.29 \mu \mathrm{g} \mathrm{g}^{-1}$ soil were recorded at $\mathrm{T}_{\mathbf{1}}(100 \%$ recommended dose of $\mathrm{N}$ ). The data on PMEase activity as influenced by different INM practices are presented in Table 6. The differences in PMEase activity were highly significant over $\mathrm{T}_{\mathbf{1}}$ (100\% recommended dose of $\mathrm{N}$ ) with the highest PMEase activity of 356.44 and $382.46 \mu \mathrm{g} p$-nitrophenol $\mathrm{g}^{-1}$ soil hour $^{-1}$ at $\mathrm{T}_{6}(50 \% \mathrm{RD}$ of $\mathrm{N}+25 \% \mathrm{~N}$ through Enriched compost $+25 \% \mathrm{~N}$ through Vermicompost) in 2014-15 and 2015-16 respectively.

Table 7 showed the data on Dehydrogenase activity which was found to be highly significant. The data revealed that during the year 2014-15 and 2015-16 the highest Dehydrogenase activity of 191.29 and $201.19 \mu \mathrm{g} \mathrm{TPFg}^{-1}$ soil 24 hour $^{-1}$ were recorded at $\mathrm{T}_{6}(50 \% \mathrm{RD}$ of $\mathrm{N}+25 \% \mathrm{~N}$ through Enriched compost $+25 \% \mathrm{~N}$ through Vermicompost) and the lowest DH activity of 164.66 and $168.37 \mu \mathrm{g} \mathrm{TPFg}^{-1}$ soil 24 hour $^{-1}$ respectively in the year 2014-15 and 2015-16 were recorded at $\mathrm{T}_{1}(100 \%$ recommended dose of $\mathrm{N}$ ). 
Table.1 Physico-chemical properties of surface soil $(0-15 \mathrm{~cm})$ of the experimental site

\begin{tabular}{|c|c|c|c|}
\hline Sl. No. & Soil property & Value & Inference \\
\hline \multicolumn{4}{|c|}{ A. Mechanical fraction $\%$} \\
\hline 1. & Sand & 51.52 & \\
\hline 2. & Silt & 24.40 & Sandy loam \\
\hline 3. & Clay & 15.48 & \\
\hline 4. & Soil reaction $(\mathrm{pH})$ & 5.56 & Acidic \\
\hline 6. & Organic carbon $(\%)$ & 0.72 & Medium \\
\hline 7. & Available N (kg/ha) & 290 & Medium \\
\hline 8. & Available $\mathrm{P}_{2} \mathrm{O}_{5}(\mathrm{~kg} / \mathrm{ha})$ & 25.78 & Medium \\
\hline 9. & Available $\mathrm{K}_{2} \mathrm{O}$ (kg/ha) & 270.89 & Medium \\
\hline
\end{tabular}

Table.2 Biological properties of soil

\begin{tabular}{clc}
\hline Sl. No. & Characteristics & Value \\
\hline 1. & Microbial biomass carbon $(\mu \mathrm{g} / \mathrm{g} / \mathrm{dry}$ soil $)$ & 215.44 \\
2. & Dehydrogenage activity $(\mu \mathrm{g} \mathrm{TPF} / \mathrm{g} / \mathrm{day})$ & 149.08 \\
3. & Phosphomonoesterase activity $(\mu \mathrm{g} \mathrm{PNP} / \mathrm{g} / \mathrm{hr})$ & 249.60 \\
4. & Fluorescein Di-acetate Hydrolysis Activity $(\mu \mathrm{g}$ fluorescein $/ \mathrm{g}$ soil $/ \mathrm{hr})$ & 4.92 \\
\hline
\end{tabular}

Table.3 Available NPK status in soil at harvest as influenced by different INM practices

\begin{tabular}{|c|c|c|c|c|c|c|}
\hline \multirow[t]{2}{*}{ Treatments } & \multicolumn{4}{|c|}{ Available $N\left(\mathrm{~kg} \mathrm{ha}^{-1}\right)$ Available $P\left(\mathrm{~kg} \mathrm{ha}^{-1}\right)$} & \multicolumn{2}{|c|}{ Available $K\left(\mathrm{~kg} \mathrm{ha}^{-1}\right)$} \\
\hline & 2014-15 & 2015-16 & 2014-15 & 2015-16 & 2014-15 & 2015-16 \\
\hline $\mathrm{T}_{1}: 100 \% \mathrm{RD}$ of $\mathrm{N}$ & 347.33 & 388.20 & 20.25 & 20.65 & 116.00 & 117.53 \\
\hline $\begin{array}{l}\mathrm{T}_{2}: 75 \% \mathrm{RD} \text { of } \mathrm{N}+25 \% \mathrm{~N} \text { through } \\
\text { Enriched compost }\end{array}$ & 328.33 & 375.88 & 20.88 & 21.00 & 120.84 & 121.03 \\
\hline $\begin{array}{l}\mathrm{T}_{3}: 75 \% \mathrm{RD} \text { of } \mathrm{N}+25 \% \mathrm{~N} \text { through } \\
\text { Vermicompost }\end{array}$ & 311.00 & 505.15 & 22.77 & 22.11 & 306.16 & 306.44 \\
\hline $\begin{array}{l}\mathrm{T}_{4}: 50 \% \mathrm{RD} \text { of } \mathrm{N}+50 \% \mathrm{~N} \text { through } \\
\text { Enriched compost }\end{array}$ & 384.67 & 535.06 & 22.90 & 23.74 & 327.66 & 329.33 \\
\hline $\begin{array}{l}\mathrm{T}_{5}: 50 \% \mathrm{RD} \text { of } \mathrm{N}+50 \% \mathrm{~N} \text { through } \\
\text { Vermicompost }\end{array}$ & 384.33 & 520.28 & 21.83 & 22.49 & 312.38 & 314.38 \\
\hline $\begin{array}{l}\mathrm{T}_{6}: 50 \% \mathrm{RD} \text { of } \mathrm{N}+25 \% \mathrm{~N} \text { through } \\
\text { Enriched compost }+25 \% \mathrm{~N} \\
\text { through Vermicompost }\end{array}$ & 405.00 & 548.15 & 23.20 & 23.96 & 333.89 & 336.55 \\
\hline $\begin{array}{l}\mathrm{T}_{7}: 50 \% \mathrm{RD} \text { of } \mathrm{N}+25 \% \mathrm{~N} \text { through } \\
\text { Enriched compost }\end{array}$ & 337.33 & 496.67 & 22.30 & 22.45 & 140.30 & 141.13 \\
\hline $\begin{array}{l}\mathrm{T}_{8}: 50 \% \mathrm{RD} \text { of } \mathrm{N}+25 \% \mathrm{~N} \text { through } \\
\text { Vermicompost }\end{array}$ & 301.33 & 406.00 & 21.04 & 21.21 & 147.88 & 148.28 \\
\hline S.Em $( \pm)$ & 10.94 & 3.75 & 1.16 & 1.07 & 2.91 & 2.68 \\
\hline$\overline{\mathrm{CD}(\mathrm{P}=0.05)}$ & 33.19 & $11.37 \mathrm{I}$ & & $\overline{\mathrm{NS}}$ & 8.82 & 8.13 \\
\hline
\end{tabular}


Table.4 Soil pH and organic carbon of soil as influenced by different INM practices

\begin{tabular}{|c|c|c|c|c|}
\hline \multirow[t]{2}{*}{ Treatments } & \multicolumn{2}{|c|}{ Soil pH } & \multicolumn{2}{|c|}{ Organic carbon } \\
\hline & 2014-15 & 2015-16 & 2014-15 & 2015-16 \\
\hline $\mathrm{T}_{1}: 100 \% \mathrm{RD}$ of $\mathrm{N}$ & 5.33 & 5.39 & 0.55 & 0.58 \\
\hline $\mathrm{T}_{2}: 75 \% \mathrm{RD}$ of $\mathrm{N}+25 \% \mathrm{~N}$ through Enriched compost & 5.55 & 5.60 & 0.86 & 0.95 \\
\hline $\mathrm{T}_{3}: 75 \% \mathrm{RD}$ of $\mathrm{N}+25 \% \mathrm{~N}$ through Vermicompost & 5.61 & 5.69 & 0.71 & 0.78 \\
\hline $\mathrm{T}_{4}: 50 \% \mathrm{RD}$ of $\mathrm{N}+50 \% \mathrm{~N}$ through Enriched compost & 5.58 & 5.62 & 0.84 & 0.92 \\
\hline $\mathrm{T}_{5}: 50 \% \mathrm{RD}$ of $\mathrm{N}+50 \% \mathrm{~N}$ through Vermicompost & 5.55 & 5.56 & 0.88 & 0.96 \\
\hline $\begin{array}{l}\mathrm{T}_{6}: 50 \% \mathrm{RD} \text { of } \mathrm{N}+25 \% \mathrm{~N} \text { through Enriched compost } \\
+25 \% \mathrm{~N} \text { through Vermicompost }\end{array}$ & 5.73 & 5.77 & 0.96 & 1.08 \\
\hline $\mathrm{T}_{7}: 50 \% \mathrm{RD}$ of $\mathrm{N}+25 \% \mathrm{~N}$ through Enriched compost & 5.58 & 5.60 & 0.84 & 0.95 \\
\hline $\mathrm{T}_{8}: 50 \% \mathrm{RD}$ of $\mathrm{N}+25 \% \mathrm{~N}$ through Vermicompost & 5.50 & 5.58 & 0.92 & 0.92 \\
\hline S.Em $( \pm)$ & 0.10 & 0.12 & 0.03 & 0.02 \\
\hline $\mathrm{CD}(\mathrm{P}=0.05)$ & NS & NS & 0.09 & 0.06 \\
\hline
\end{tabular}

INM- Integrated nutrient management, NS- Non- significant

Table.5 Soil microbial biomass carbon $\left(\mu \mathrm{g} \mathrm{g}^{-1}\right.$ soil) as influenced by different INM practices

Treatments
MBC

2014-15 2015-16

242.35

278.29

299.03

308.02

294.13

305.84

327.88

342.30

297.28

317.51

$\mathrm{T}_{5}: 50 \% \mathrm{RD}$ of $\mathrm{N}+50 \% \mathrm{~N}$ through Vermicompost

$\mathrm{T}_{6}: 50 \% \mathrm{RD}$ of $\mathrm{N}+25 \% \mathrm{~N}$ through Enriched compost $+25 \% \mathrm{~N}$

through Vermicompost

335.55

367.41

$\mathrm{T}_{7}: 50 \% \mathrm{RD}$ of $\mathrm{N}+25 \% \mathrm{~N}$ through Enriched compost

281.32

306.62

$\mathrm{T}_{8}: 50 \% \mathrm{RD}$ of $\mathrm{N}+25 \% \mathrm{~N}$ through Vermicompost
306.04
$\operatorname{S.Em}( \pm)$

$\mathrm{CD}(\mathrm{P}=0.05)$
14.33

43.47
4.08

12.36 
Table.6 Phosphomonoesterase Activity ( $\mu \mathrm{g}$ p-nitrophenol $\mathrm{g}^{-1}$ soil hour ${ }^{-1}$ ) as influenced by different INM practices

Treatments

\begin{tabular}{lcc}
\cline { 2 - 3 } & $\mathbf{2 0 1 4 - 1 5}$ & $\mathbf{2 0 1 5 - 1 6}$ \\
\hline $\mathrm{T}_{1}: 100 \% \mathrm{RD}$ of $\mathrm{N}$ & 280.22 & 295.85 \\
$\mathrm{~T}_{2}: 75 \% \mathrm{RD}$ of $\mathrm{N}+25 \% \mathrm{~N}$ through Enriched compost & 329.66 & 339.45 \\
$\mathrm{~T}_{3}: 75 \% \mathrm{RD}$ of $\mathrm{N}+25 \% \mathrm{~N}$ through Vermicompost & 308.01 & 311.65 \\
$\mathrm{~T}_{4}: 50 \% \mathrm{RD}$ of $\mathrm{N}+50 \% \mathrm{~N}$ through Enriched compost & 344.11 & 368.47 \\
$\mathrm{~T}_{5}: 50 \% \mathrm{RD}$ of $\mathrm{N}+50 \% \mathrm{~N}$ through Vermicompost & 342.96 & 367.22 \\
$\mathrm{~T}_{6}: 50 \% \mathrm{RD}$ of $\mathrm{N}+25 \% \mathrm{~N}$ through Enriched compost $+25 \% \mathrm{~N}$ & & \\
through Vermicompost & 356.44 & 382.46 \\
$\mathrm{~T}_{7}: 50 \% \mathrm{RD}$ of $\mathrm{N}+25 \% \mathrm{~N}$ through Enriched compost & 341.13 & 356.26 \\
$\mathrm{~T}_{8}: 50 \% \mathrm{RD}$ of $\mathrm{N}+25 \% \mathrm{~N}$ through Vermicompost & 342.78 & 349.16 \\
\hline $\mathrm{S} . \mathrm{Em}( \pm)$ & 9.26 & 7.72 \\
\hline $\mathrm{CD}(\mathrm{P}=0.05)$ & 28.10 & 23.42
\end{tabular}

INM-Integrated nutrient management

Table.7 Dehydrogenase enzyme ( $\mu \mathrm{g}_{\mathrm{TPF}} \mathrm{g}^{-1}$ soil 24 hour $\left.^{-1}\right)$ as influenced by different INM practices

\begin{tabular}{lcc} 
Treatments & Dehydrogenase & \\
\cline { 2 - 3 } & $\mathbf{2 0 1 4 - 1 5}$ & $\mathbf{2 0 1 5 - 1 6}$ \\
\hline $\mathrm{T}_{1}: 100 \% \mathrm{RD}$ of $\mathrm{N}$ & 164.66 & 168.37 \\
$\mathrm{~T}_{2}: 75 \% \mathrm{RD}$ of $\mathrm{N}+25 \% \mathrm{~N}$ through Enriched compost & 181.88 & 187.09 \\
$\mathrm{~T}_{3}: 75 \% \mathrm{RD}$ of $\mathrm{N}+25 \% \mathrm{~N}$ through Vermicompost & 179.55 & 183.80 \\
$\mathrm{~T}_{4}: 50 \% \mathrm{RD}$ of $\mathrm{N}+50 \% \mathrm{~N}$ through Enriched compost & 188.56 & 198.16 \\
$\mathrm{~T}_{5}: 50 \% \mathrm{RD}$ of $\mathrm{N}+50 \% \mathrm{~N}$ through Vermicompost & 183.12 & 187.80 \\
$\mathrm{~T}_{6}: 50 \% \mathrm{RD}$ of $\mathrm{N}+25 \% \mathrm{~N}$ through Enriched compost $+25 \% \mathrm{~N}$ & & \\
through Vermicompost & 191.29 & 201.19 \\
$\mathrm{~T}_{7}: 50 \% \mathrm{RD}$ of $\mathrm{N}+25 \% \mathrm{~N}$ through Enriched compost & 178.15 & 181.44 \\
$\mathrm{~T}_{8}: 50 \% \mathrm{RD}$ of $\mathrm{N}+25 \% \mathrm{~N}$ through Vermicompost & 177.58 & 180.26 \\
\hline $\mathrm{S} . \mathrm{Em}( \pm)$ & 3.15 & 2.42 \\
\hline $\mathrm{CD}(\mathrm{P}=0.05)$ & 9.57 & 7.34 \\
\hline
\end{tabular}

INM-Integrated nutrient management 
Table.8 Fluorescein di-acetate hydrolysis activity ( $\mu$ g fluorescein $\mathrm{g}^{-1} \mathrm{~h}^{-1}$ ) as influenced by different INM practices

Treatments

FDA

2014-15

2015-16

$\mathrm{T}_{1}: 100 \% \mathrm{RD}$ of $\mathrm{N}$

6.34

6.66

$\mathrm{T}_{2}: 75 \% \mathrm{RD}$ of $\mathrm{N}+25 \% \mathrm{~N}$ through Enriched compost

7.98

9.15

$\mathrm{T}_{3}: 75 \% \mathrm{RD}$ of $\mathrm{N}+25 \% \mathrm{~N}$ through Vermicompost

8.05

$\mathrm{T}_{4}: 50 \% \mathrm{RD}$ of $\mathrm{N}+50 \% \mathrm{~N}$ through Enriched compost

9.10

9.15

$\mathrm{T}_{5}: 50 \% \mathrm{RD}$ of $\mathrm{N}+50 \% \mathrm{~N}$ through Vermicompost

7.96

8.15

$\mathrm{T}_{6}: 50 \% \mathrm{RD}$ of $\mathrm{N}+25 \% \mathrm{~N}$ through Enriched compost $+25 \% \mathrm{~N}$

9.22

9.26

through Vermicompost

$\mathrm{T}_{7}: 50 \% \mathrm{RD}$ of $\mathrm{N}+25 \% \mathrm{~N}$ through Enriched compost

7.10

$\mathrm{T}_{8}: 50 \% \mathrm{RD}$ of $\mathrm{N}+25 \% \mathrm{~N}$ through Vermicompost

7.22

7.62

$\operatorname{S.Em}( \pm)$

0.09

0.06

$\mathrm{CD}(\mathrm{P}=0.05)$

0.27

0.18

INM-Integrated nutrient management

Fig.1 Relationship of Av. N (kg/ha) with the organic carbon (\%) after harvest of potato

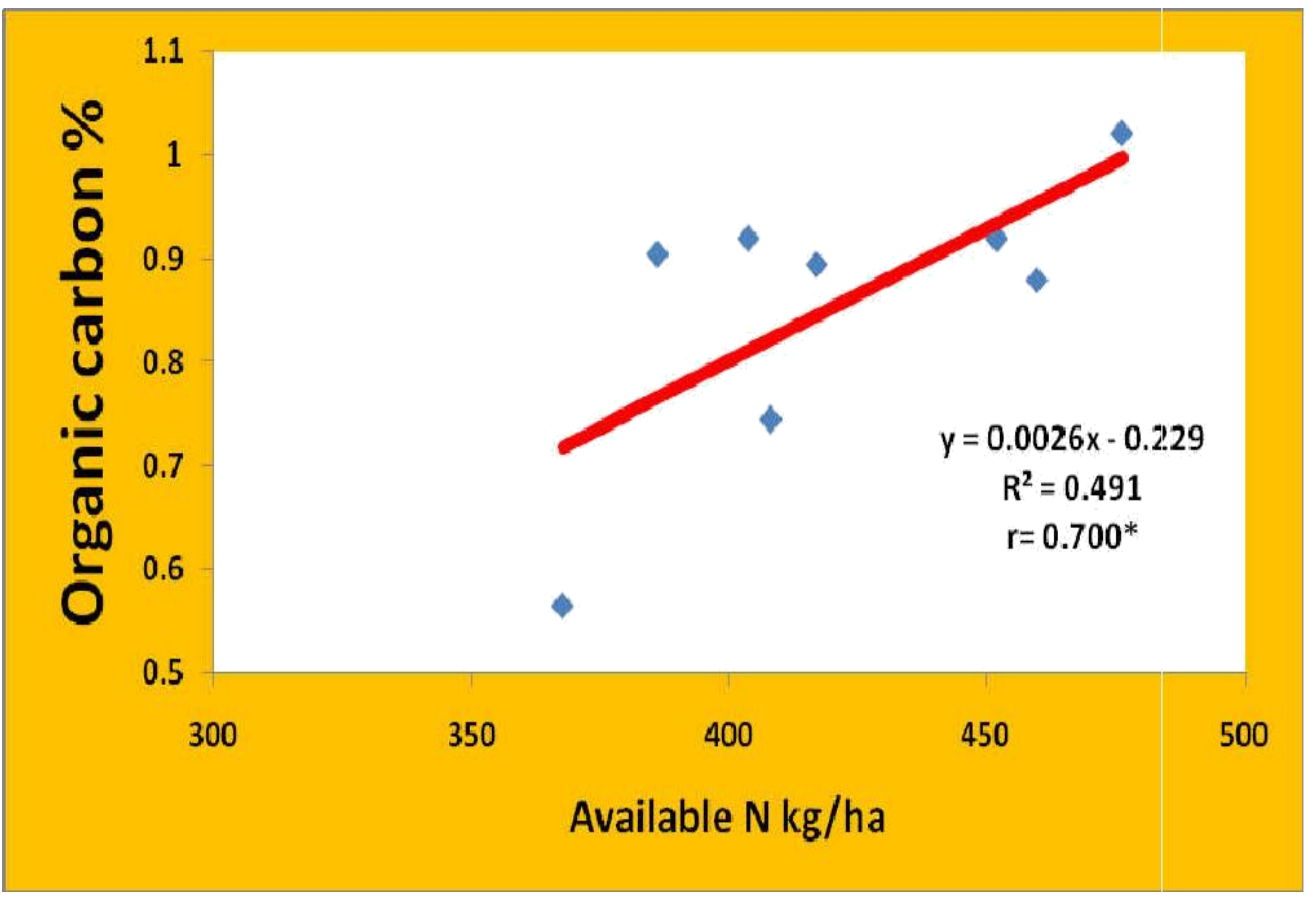


Fig.2 Relationship of Av. $\mathrm{P}_{2} \mathrm{O}_{5}$ with the enzyme phosphomonoesterase ( $\mu \mathrm{g} p$-nitrophenol $\mathrm{g}^{-1} \mathrm{~h}^{-1}$ ) after harvest of potato

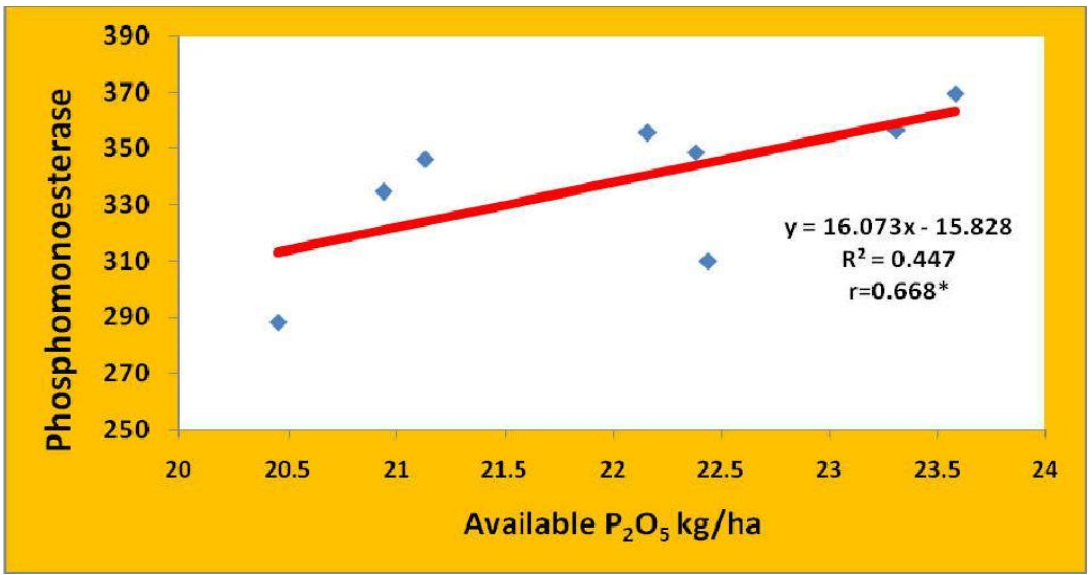

Fig.3 Relationship of dehydrogenase ( $\mu \mathrm{g} \mathrm{TPF} \mathrm{g}{ }^{-1} 24 \mathrm{~h}^{-1}$ ) with the organic carbon after harvest of potato

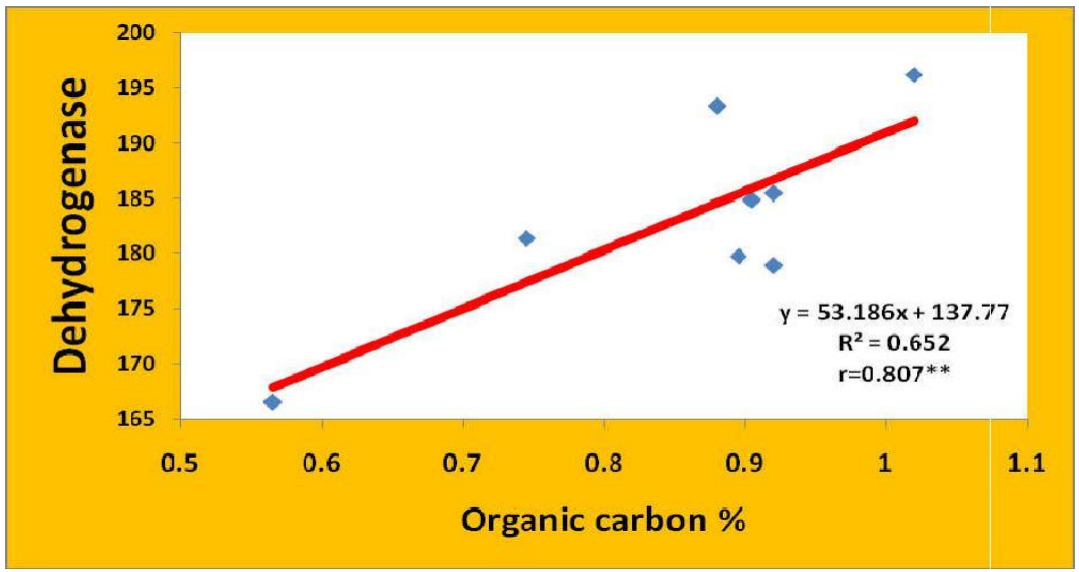

Fig.4 Relationship of MBC $\left(\mu \mathrm{g} \mathrm{g}^{-1}\right)$ with the organic carbon after harvest of potato

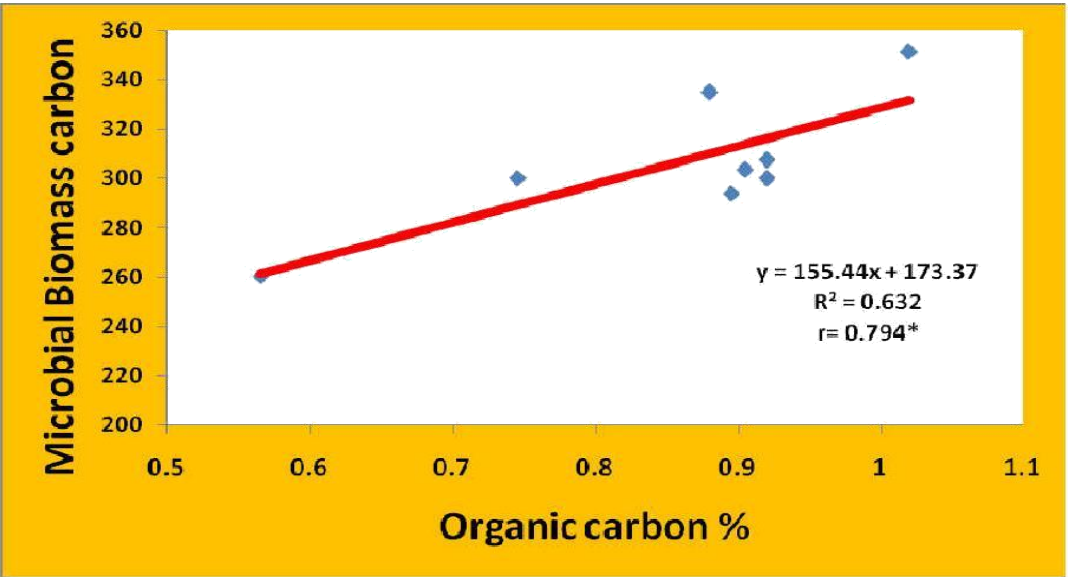


Fig.5 Relationship of MBC $\left(\mu \mathrm{g} \mathrm{g}^{-1}\right)$ with the enzymes dehydrogenase $\left(\mu \mathrm{g} \mathrm{TPF} \mathrm{g}^{-1} 24 \mathrm{~h}^{-1}\right)$ after harvest of potato

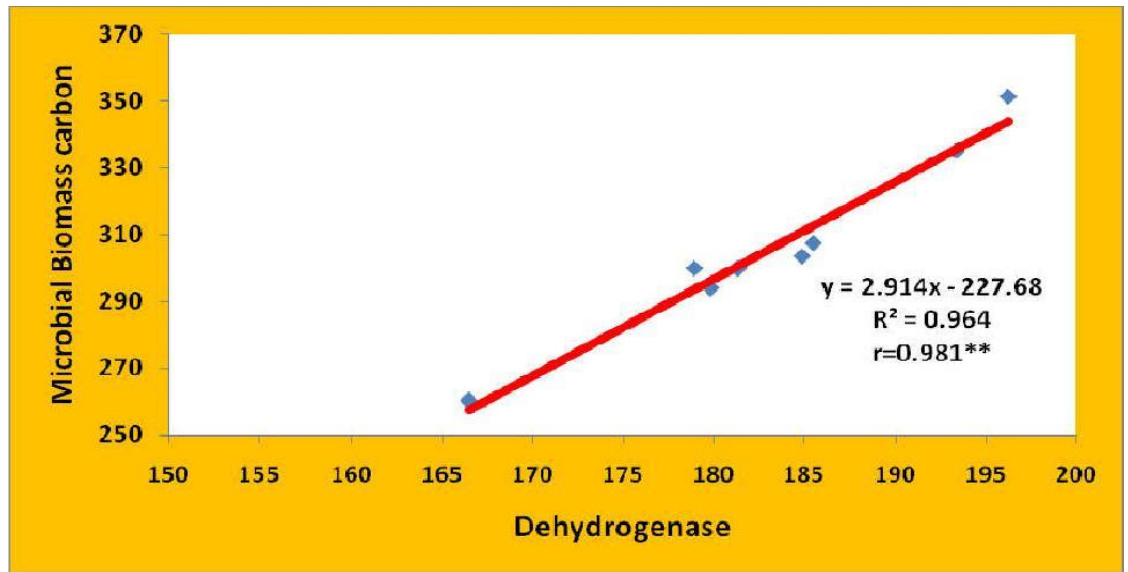

Data on fluorescein di-acetate activity as influenced by different INM practices are presented in Table 8 . The data revealed that during the year 2014-15 and 2015-16, the highest fluorescein di- acetate activity of 9.22 and $9.26 \mu \mathrm{g}$ fluorescein $\mathrm{g}^{-1} \mathrm{~h}^{-1}$ was recorded at $\mathrm{T}_{6}(50 \% \mathrm{RD}$ of $\mathrm{N}+25 \% \mathrm{~N}$ through Enriched compost $+25 \% \mathrm{~N}$ through Vermicompost) and then followed by 9.10 and $9.15 \mu \mathrm{g}$ fluorescein $\mathrm{g}^{-1} \mathrm{~h}^{-1}$ at $\mathrm{T}_{4}(75 \% \mathrm{RD}$ of $\mathrm{N}+25 \%$ $\mathrm{N}$ through Vermicompost). The lowest fluorescein diacetate 6.34 and $6.66 \mu \mathrm{g}$ fluorescein $\mathrm{g}^{-1} \mathrm{~h}^{-1}$ activity were recorded at $\mathrm{T}_{1}$ (100\% recommended dose of $\mathrm{N}$ ) during both the years.

The two years data revealed that $T_{1}(100 \%$ recommended dose of $\mathrm{N}$ ) recorded the lowest soil organic carbon of $0.55 \%$ and $0.58 \%$ respectively. However, maximum values (0.96 and $1.08 \%)$ of organic carbon were recorded at $\mathrm{T}_{6}(50 \% \mathrm{RD}$ of $\mathrm{N}+25 \% \mathrm{~N}$ through Enriched compost $+25 \% \mathrm{~N}$ through Vermicompost).

This increase might be due to direct addition of organic source of nutrients and less mineralization due to wide $\mathrm{C}$ : $\mathrm{N}$ ratio in fertilizer. Increased organic carbon due to addition of organic manures was reported by Sharma and Mitra (1990), Nethra et al.,
(1999) and Gupta et al., (2000). Post-harvest available $\mathrm{N}, \mathrm{P}$ and $\mathrm{K}$ in soil are important aspects to evaluate the soil fertility status required for sustaining the soil health and crop productivity. In this experiment, INM increased the post-harvest available $\mathrm{N}, \mathrm{P}, \mathrm{K}$ status in soil during both the years.

The experimental findings on gain or loss of available soil N, P, K revealed that addition of organic inputs along with fertilizers had positive effect on this attribute. In both the years, the treatment $50 \% \mathrm{RD}$ of $\mathrm{N}+25 \% \mathrm{~N}$ through Enriched compost $+25 \% \mathrm{~N}$ through Vermicompost $\left(\mathrm{T}_{6}\right)$ produced higher available $\mathrm{N}, \mathrm{P}$ and $\mathrm{K}$ in soil followed by $\mathrm{T}_{4}(50 \% \mathrm{RD}$ of $\mathrm{N} 50 \% \mathrm{~N}$ through Enriched compost).

This might be attributed to the beneficial effect of INM on soil properties. These findings are in consonance with those of Meelu (1981), Hesse (1984), Budhar et al., (1991) and Khalak and Kumaraswamy (1993) [They also reported the positive effect of organic sources on soil fertility status with reference to nitrogen, phosphorous and potassium].

INM treatments exerted significant influence on soil biomass carbon with highest values of 335.55 and $367.41 \mu \mathrm{g} \mathrm{g}^{-1}$ soil at $\mathrm{T}_{6}(50 \% \mathrm{RD}$ 
of $\mathrm{N}+25 \% \mathrm{~N}$ through Enriched compost + $25 \% \mathrm{~N}$ through Vermicompost) during 2014-15 and 2015-16 (Table 5). Similar results were observed in case of dehydrogenase, Phosphomonoesterase activity and fluorescein di-acetate activity. Study of soil enzymes gives information about the release of nutrients in soil by means of organic matter degradation and microbial activity as well as indicators of ecological change. Soil enzymes analysis helps to establish correlation with soil fertilization, microbial activity and biochemical cycling of various elements in soil.

Application of enriched compost, Vermicompost and biofertilizer in INM, resulted in a significant correlation (Fig. 1, 2, 3, 4 and 5) with microbial biomass carbon (MBC), organic carbon (OC), available $\mathrm{N}$, $\mathrm{P}_{2} \mathrm{O}_{5}$ and enzyme activities. The organic carbon showed strong correlation with Microbial biomass carbon $(\mathrm{r}=0.794 *)$, Dehydrogenase $(\mathrm{r}=0.807 * *)$ and Av. Nitrogen $\left(\mathrm{r}=0.700^{*}\right)$. Similarly the enzyme phosphomonoesterase established significant correlation with Av. $\mathrm{P}_{2} \mathrm{O}_{5} \quad\left(\mathrm{r}=0.668^{*}\right)$ indicating the role of enzyme in releasing the $\mathrm{P}$ from organic sources and also MBC showed significant correlation with dehydrogenase $(\mathrm{r}=0.981 * *)$.

It can be stated that the regular use of organic inputs coupled with chemical fertilizer can improve the chemical and biological properties of soil under potato and its residual effect on green gram. In particular, use of enriched compost with low amount of chemical fertilizer improved the soil enzyme activities, microbial biomass carbon, microbial population as well as organic carbon concentration in soil under the sequence (Nath et al., 2012).

Based on the results of two years experimentation, it can be concluded that the integrated use of inorganic and organic sources of nutrients proved superior to inorganic alone in respect of yield and other growth characters. The integrated nutrient management treatment equally improved the physico-chemical and biological properties of the soil. Considering the positive effects of integrated nutrient management on growth and yield of potato crop and soil health, combination of $50 \%$ recommended dose of $\mathrm{N}$ $+25 \% \mathrm{~N}$ through enriched compost $+25 \% \mathrm{~N}$ through vermicompost $\left(\mathrm{T}_{\mathbf{6}}\right)$ was found to be the best.

\section{Acknowledgements}

Authors are sincerely thankful to the Department of Agronomy and Department of Soil Science, Assam Agricultural University for providing necessary facilities to conduct the experiment.

\section{References}

Budhar, M. N., Palaniappan, S. P. and Rangaswami, A. (1991). Effect of farm waste and green manures on lowland rice. Ind. J. Agron. 36 (2): 251-252.

Gupta, R. K.; Arora, B. R.; Sharma, K. N. and Ahluwalia, S. K. (2000). Influence of biogas slurry and farm yard manure application on the changes in soil fertility under rice-wheat sequence. $J$. Indian Soc. Soil Sci. 48: 500-505.

Hesse, P. R. (1984). Potential of organic materials for soil improvement. In: Organic matter and rice, IRRI, Philippines, pp. 38-39.

Khalak and Kumaraswamy A. S. (1993). Balance sheet of nitrogen, phosphorus and potassium as influenced by irrigation and fertilizer application in potato based cropping systems. $J$. Indian potato Assoc. 20 (2): 111-116.

Meelu O P. (1981). Integrated use of fertilizers and manures in cropping sequence. Indian Farming 31: 75-79. 
Nath, D. J., Ozah, B., Baruah, R., Barooah, R. C., Borah, D. K. and Gupta, M. (2012). Soil enzymes and microbial biomass carbon under Rice-Toria sequence as influenced by nutrient management. $J$. Indian Soc. Soil Sci. 60: 20-24.

Nethra, N. N., Jayaprasad, K. V. and Kale, R. D. (1999). China aster (Callistephus chinensis L., Ness) cultivation using vermicompost as organic amendment, Hissar. Crop Res. 17: 209-215.

Sharma, A. R. and Mitra, B. N. (1990). Complementary effect of organic bio and mineral fertilizers in rice based cropping system. Fert. News 35(2): 43-51.

\section{How to cite this article:}

Chutia, R., P.C. Bhagawati and Nath, D.J. 2017. Effect of Biofertilizer and Integrated Nutrient Management on Growth of Potato and Soil Microbial Activity. Int.J.Curr.Microbiol.App.Sci. 6(12): 355-365. doi: https://doi.org/10.20546/ijcmas.2017.612.043 